\title{
Sex-specific variations in phytochemicals and antimicrobial potentiality of Dioscorea
}

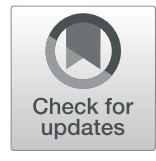

\author{
Chiranjit Paul $^{1 *}$, Amal Debnath ${ }^{1}$, Kripamoy Chakraborty ${ }^{2}$, Sushanta Ghosh ${ }^{3}$, Abhijit Bhattacharjee ${ }^{1}$ and \\ Bimal Debnath ${ }^{1}$
}

\begin{abstract}
Background: The monocotyledonous herbaceous crop Dioscorea is native to tropical and temperate regions of the world. Dioscorea tubers are dioecious in nature, have colossal therapeutic potentiality, and are frequently used in traditional medical practices throughout the world. Most of the research works are aimed to determine the medicinal property, nutritions, antinutrients, and biological activities of Dioscorea spp. without specifying the sexes of Dioscorea which promoted us to carry out this present research work.

Results: Sex-specific variation of phytoconstituents, antioxidants, and antimicrobial efficiency in tubers was appraised. The results obtained from this study divulge existence of significant quantitative variation between the male and female tubers. The female tubers are superior in acquiring phytochemicals compared to male counterparts and acquired maximum antioxidant and antimicrobial potentiality.

Conclusion: This study will offer an apposite baseline for further sex-specific assessment which can be directed towards both qualitative and quantitative amelioration of medicinally important noble compounds by exploiting modern scientific strategies leading to their active participation in nutraceutical industries.
\end{abstract}

Keywords: Sex-specificity, Phytoconstituents, Antioxidant, Baseline, Nutraceutical industry

\section{Background}

The genus Dioscorea earlier positioned under order Liliales [1] but later included under Dioscoreales [2]. The highly medicinal dioecious Dioscorea of Dioscoreaceae contains more than 600 species globally [3-5]. The Dioscorea tubers are renowned for their ethnobotanical, nutritive, antioxidant, and biological potentiality that ensure the quality of daily nourishment of the indigenous people $[4,6,7]$. Dioscorea (Yam) is a staple food for the people of tropical countries of Africa, Asia, Caribbean, and the Pacific region [8]. The long-term storage potentiality of these tubers ensures seasonal food security in developing countries [9]. Diosgenin is a phytosteroidal saponin and a major bioactive compound found in the

\footnotetext{
*Correspondence: chiranjit.paul869@gmail.com

'Plant Diversity and Forest Biotechnology Laboratory, Department of Forestry and Biodiversity, Tripura University, Suryamaninagar, Agartala, Tripura 799022, India

Full list of author information is available at the end of the article
}

roots of wild yam [10]. It is the main precursor in the manufacture of synthetic steroids in the pharmaceutical industries [11].

Dioecy is attributed to seven percent of total plant taxa although most of the medicinal plants are monoecious [12]. Knowledge of the dioecious nature of plants has existed since Babylonian times but their consequences in the traditional medical system are not recognized appropriately [13]. Insinuation of dioecy in chemical and pharmacological properties has been pointed out [14-16]. The sex-specific biological activities of Piper betle, Carica papaya, and Tinospora cordifolia was recorded [17-19]. Sex determination in Dioscorea has not yet been fully elucidated although [20-22] have favored male as the heterogametic sex; Smith [22] and Meurman [23] emphasized the occurrence of an extra chromosome for the male expression, while [23-25] have reported absence of sex chromosomes. Literature survey concerning the biological potentiality and phytoconstituents' availability underpin
Springer Open

(c) The Author(s). 2020 Open Access This article is licensed under a Creative Commons Attribution 4.0 International License, which permits use, sharing, adaptation, distribution and reproduction in any medium or format, as long as you give appropriate credit to the original author(s) and the source, provide a link to the Creative Commons licence, and indicate if changes were made. The images or other third party material in this article are included in the article's Creative Commons licence, unless indicated otherwise in a credit line to the material. If material is not included in the article's Creative Commons licence and your intended use is not permitted by statutory regulation or exceeds the permitted use, you will need to obtain permission directly from the copyright holder. To view a copy of this licence, visit http://creativecommons.org/licenses/by/4.0/. 
that evaluation of sex-specific variation concerning phytoconstituents and biological efficacy of Dioscorea spp. has remained unexplored although reports are available [7].

Hence, this present study has entrained to evaluate the variation in the phytoconstituents and antimicrobial efficiency based on the male and female tubers of Dioscorea.

\section{Methods}

\section{Sample collection}

Matured male and female tubers of five edible Dioscorea were collected by using the shrivel and auger and packed into marked zipped sterile polythene bags from the forest bed of Tripura (Figs. 1, 2, 3, and 4). The collected plant samples were identified by using the Flora of Tripura [26], and two of them are a new addition to the
Flora of the state [27, 28]. Flowers, micro- and macromorphological characters were considered during the identification of the male and female plants and further authenticated with taking help from the expertise from Botanical Survey of India (Eastern Regional Centre, Shillong). The herbarium prepared for the selected Dioscorea spp. with their respective voucher numbers were deposited in the departmental herbarium and depicted (Table 1). Analysis of International Union for Conservation of Nature (IUCN) status pointed out that among five of the selected Dioscorea spp., only Dioscorea wallichii is included in least concern category.

\section{Plant samples}

The male and female tubers of five Dioscorea spp. were collected during the flowering phase, and photographs
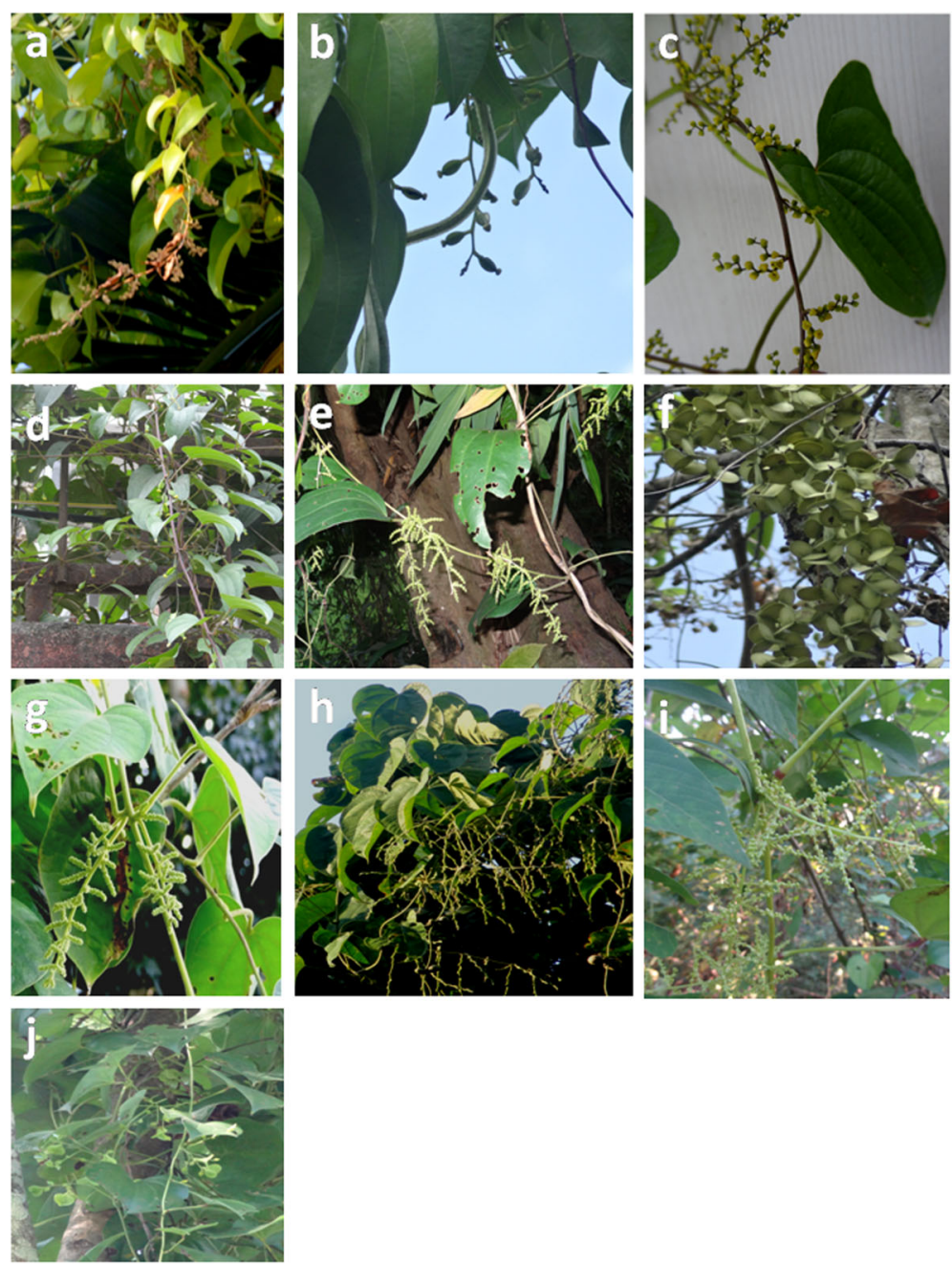

Fig. 1 Male and female plants of Dioscorea spp. with their respective reproductive structure. $\mathbf{a}, \mathbf{b}$ Male and female plants of Dioscorea alata. $\mathbf{c}$, $\mathbf{d}$ Male and female plants of Dioscorea hamiltonii. e, $\mathbf{f}$ Male and female plants of Dioscorea oppositifolia. $\mathbf{g}, \mathbf{h}$ Male and female plants of Dioscorea pubera. $\mathbf{i}, \mathbf{j}$ Male and female plants of Dioscorea wallichii 

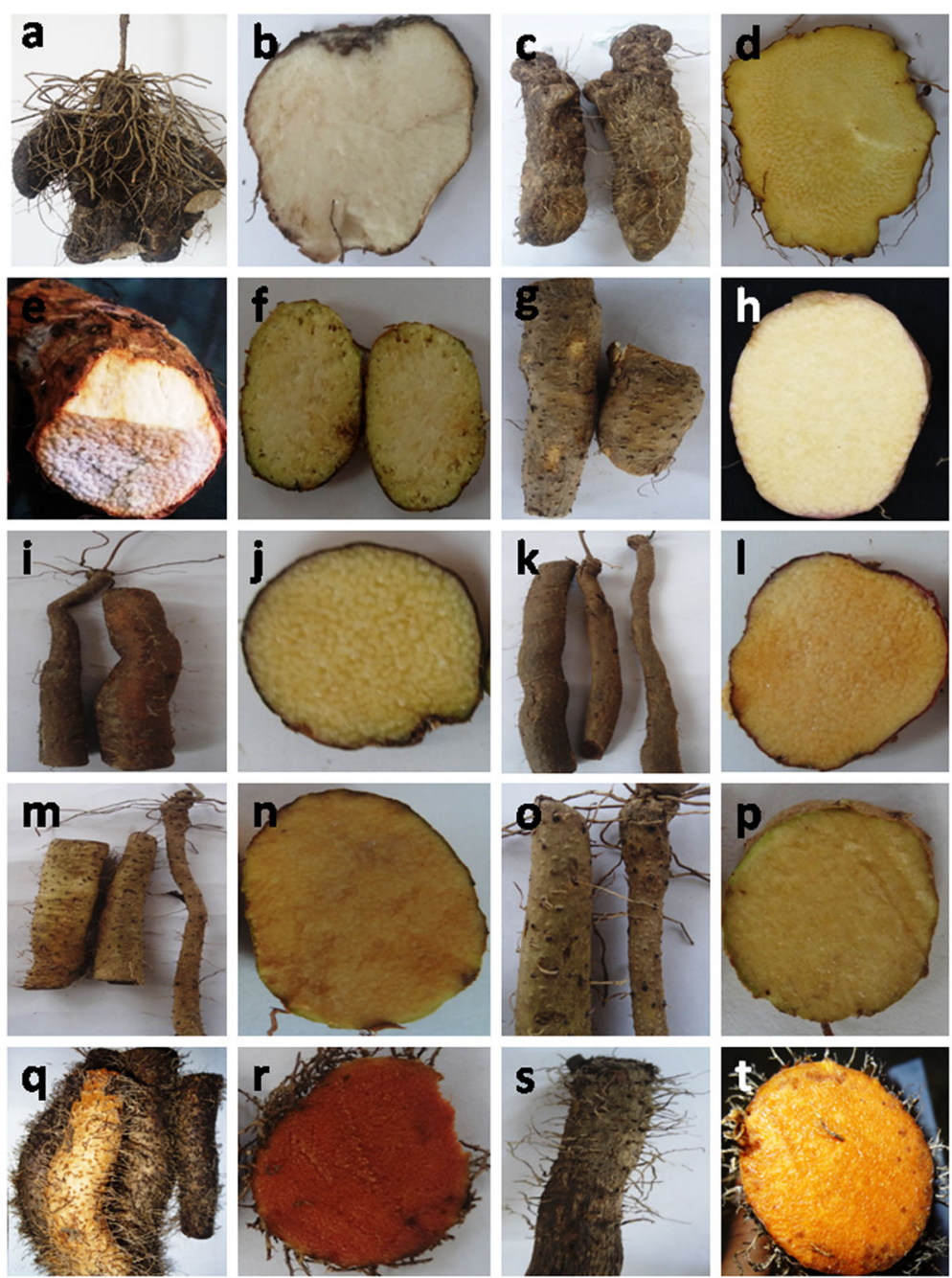

Fig. 2 Tubers and transverse section of tuber of different Dioscorea spp. a, b Male and female plants of Dioscorea alata. $\mathbf{c}$, d Male and female plants of Dioscorea hamiltonii. e, $\mathbf{f}$ Male and female plants of Dioscorea oppositifolia. $\mathbf{g}, \mathbf{h}$ Male and female plants of Dioscorea pubera. $\mathbf{i}, \mathbf{j}$ Male and female plants of Dioscorea wallichii

were taken as reference for the identification from the forest bed of three different districts of Tripura (Table 1). Care was taken during the collection of the tubers that the tubers of both male and female plants were available at each of the selected study sites.

\section{Sample extraction}

Collected tubers were cleaned in running tap water, shade dried, and pulverized to powder in a mechanical grinder. Twenty grams tuber powder of each of the Dioscorea species was extracted separately with methanol $(200 \mathrm{~mL})$ in a shaker at room temperature. After, overnight extracts were filtered through Whatman No. 1 filter paper. The filtrates were subjected to analysis for total phenolic, flavonoid contents, and DPPH radical scavenging activities.

\section{Determination of moisture content}

Tubers samples were chopped into small pieces by using sterilized blades. Ten grams of the chopped samples were taken in the previously weighed Petri plates. Then, the sample was kept in a hot-air oven for overnight at $100 \pm 2^{\circ} \mathrm{C}$. The dried samples were cooled at room temperature and weighed to a constant weight. The loss in weight was considered as the moisture percentage and was calculated by using the following formula:

Percentage of moisture content $(\%)=\frac{\mathrm{W} 1-\mathrm{W} 2 \times 100}{\mathrm{~W} 1}$ where $W_{1}=$ weight of the sample (leaf and rhizome) taken and $W_{2}=$ weight of the oven-dried samples.

\section{Determination of carbohydrate}

Carbohydrate was determined [29] from the dried tuber samples. One hundred milligrams of the sample was 

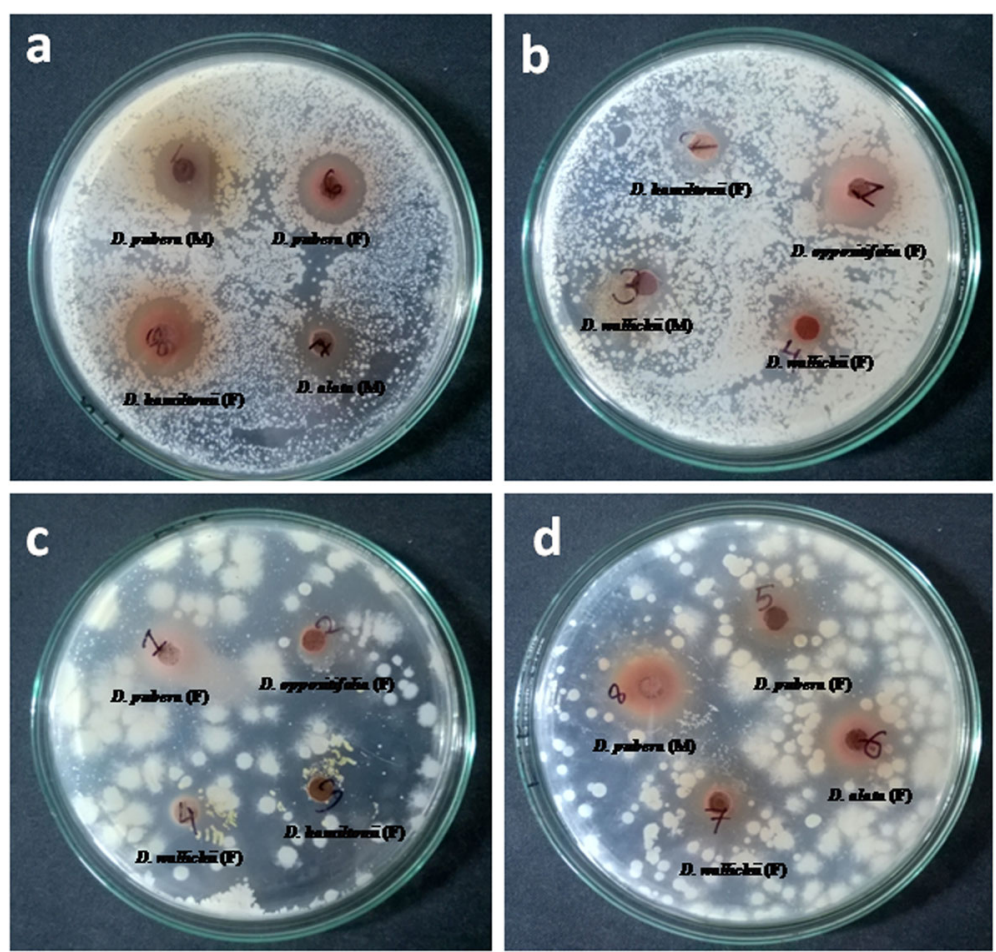

Fig. 3 Antimicrobial activity of male and female tubers of Dioscorea spp. a, b Antibacterial activity of male and female tubers of Dioscorea spp. against Streptococcus pneumoniae (MTCC-655) and Shigella dysenteriae (MTCC-227). c, d Antifungal activity of male and female tubers of Dioscorea spp. against Candida tropicalis (Agartala medical college) and Candida albicans (MTCC-227)

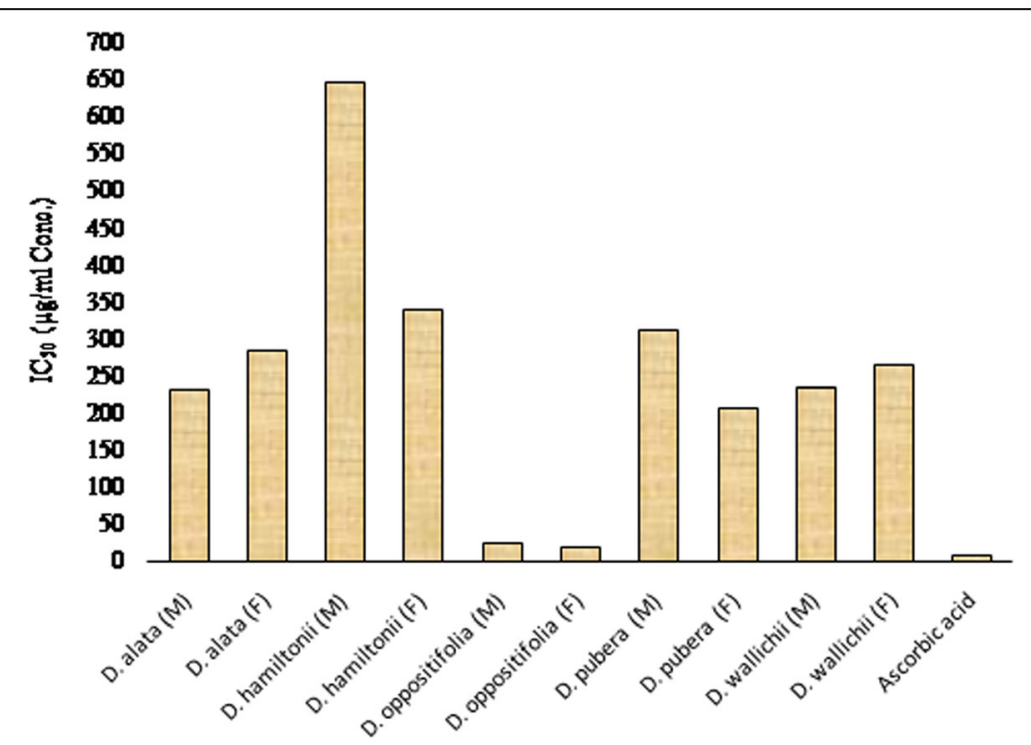

Fig. 4 Inhibition concentration $\left(\mathrm{IC}_{50}\right)$ values of male and female tubers of Dioscorea spp. and ascorbic acid 
Table 1 Location of the collection site and herbarium voucher numbers Dioscorea found in Tripura

\begin{tabular}{|c|c|c|c|c|}
\hline Plant Name & Voucher no & Collection site & District & Geographical location \\
\hline Dioscorea alata $\mathrm{L}$. & FBD121 (M) FBD122 (F) & Khowai & Khowai & $\begin{array}{l}24^{\circ} 02^{\prime} 12^{\prime \prime} \mathrm{N} 91^{\circ} 37^{\prime} 21^{\prime \prime} \text { E } 43 \mathrm{~m} \text { asl (M) } \\
24^{\circ} 02^{\prime} 13^{\prime \prime} \mathrm{N} 91^{\circ} 37^{\prime} 31^{\prime \prime} \text { E } 50 \mathrm{~m} \text { asl (F) }\end{array}$ \\
\hline Dioscorea hamiltonii Hook. F. & FBD141 (M) FBD142 (F) & Debipur & South Tripura & $\begin{array}{l}23^{\circ} 10^{\prime} 21^{\prime \prime} \mathrm{N} 91^{\circ} 31^{\prime} 14^{\prime \prime} \text { E } 53 \mathrm{~m} \text { asl (M) } \\
23^{\circ} 10^{\prime} 23^{\prime \prime} \mathrm{N} 91^{\circ} 31^{\prime} 08^{\prime \prime} \text { E } 39 \mathrm{~m} \text { asl (F) }\end{array}$ \\
\hline Dioscorea oppositifolia L. & FBD134 (M) FBD135 (F) & Santirbazar & South Tripura & $\begin{array}{l}23^{\circ} 17^{\prime} 51^{\prime \prime} \mathrm{N} 91^{\circ} 34^{\prime} 24^{\prime \prime} \text { E } 39 \mathrm{~m} \text { asl (M) } \\
23^{\circ} 18^{\prime} 58^{\prime \prime} \mathrm{N} 91^{\circ} 33^{\prime} 35^{\prime \prime} \text { E } 49 \mathrm{~m} \text { asl (F) }\end{array}$ \\
\hline Dioscorea pubera Blume & FBD119 (M) FBD120 (F) & Birchandranagar & South Tripura & $\begin{array}{l}23^{\circ} 23^{\prime} 34^{\prime \prime} \mathrm{N} 91^{\circ} 30^{\prime} 11^{\prime \prime} \text { E } 42 \mathrm{~m} \text { asl (M) } \\
23^{\circ} 22^{\prime} 22^{\prime \prime} \mathrm{N} 91^{\circ} 30^{\prime} 50^{\prime \prime} \text { E } 45 \mathrm{~m} \text { asl (F) }\end{array}$ \\
\hline Dioscorea wallichii Hook & FBD170 (M) FBD171 (F) & Dalak & Gomati & $\begin{array}{l}23^{\circ} 30^{\prime} 21^{\prime \prime} \mathrm{N} 91^{\circ} 41^{\prime} 58^{\prime \prime} \text { E } 65 \mathrm{~m} \text { asl (M) } \\
23^{\circ} 30^{\prime} 22^{\prime \prime} \mathrm{N} 91^{\circ} 42^{\prime} 06^{\prime \prime} \text { E } 71 \mathrm{~m} \text { asl (F) }\end{array}$ \\
\hline
\end{tabular}

$M$ male, $F$ female, $F B D$ Forestry and Biodiversity

taken into boiling tubes and hydrolyzed with $5 \mathrm{ml}$ of 2.5 $\mathrm{N}-\mathrm{HCl}$ for $3 \mathrm{~h}$ and cooled at room temperature flowed by the neutralization with sodium carbonate pellets. The volume is made up to $10 \mathrm{ml}$ and centrifuged at $5000 \mathrm{rpm}$ for $15 \mathrm{~min}$. The supernatant was collected and $1 \mathrm{ml}$ aliquots were taken for analysis. Then, $4 \mathrm{ml}$ of $2 \%$ anthrone (w/v in concentrated $\mathrm{H}_{2} \mathrm{SO}_{4}$ ) reagent was added and heated in a boiling water bath for $10 \mathrm{~min}$. The absorbance was taken at $630 \mathrm{~nm}$ using a spectrophotometer. Glucose was used as a standard.

\section{Determination of protein}

The protein content was determined [30]. One hundred milligrams of the sample was ground well with a pestle and mortar in $10 \mathrm{ml}$ of the potassium phosphate buffer $(0.1 \mathrm{M}, \mathrm{pH} 7.5)$ and centrifuged at $5000 \mathrm{rpm}$ for $15 \mathrm{~min}$. The pellet was discarded and the supernatant was used for protein estimation. From the supernatant, $1 \mathrm{ml}$ of sample was taken in dried test tubes and $5 \mathrm{ml}$ of reagent "C" was added. The reagent " $C$ " was prepared by mixing reagent " $A$ " and reagent " $B$ " in a ratio $50: 1 \mathrm{v} / \mathrm{v}$. Reagent "A" is the mixture of $2 \% \mathrm{Na}_{2} \mathrm{CO}_{3}$ and $0.1 \mathrm{~N} \mathrm{NaOH}$ and reagent " $\mathrm{B}$ " is a mixture of $0.5 \% \mathrm{CuSO}_{4}$ and $1 \% \mathrm{Na}-\mathrm{K}$ tartrate. The solution was shaken vigorously and allowed to stand for $20 \mathrm{~min}$. After that, $0.5 \mathrm{ml}$ of Folin-Ciocalteu reagent was added and incubated at room temperature for $30 \mathrm{~min}$. Absorbance was measured at $660 \mathrm{~nm}$ using a spectrophotometer. Bovine serum albumin (BSA) was used as a standard.

\section{Estimation of total free amino acids}

The amount of total free amino acid was estimated [31]. For this, $100 \mathrm{mg}$ of dried tubers sample was homogenized in $10 \mathrm{ml}$ of $50 \%$ aqueous ethanol with a pinch of activated charcoal. The slurry was centrifuged at 5000 rpm for $10 \mathrm{~min}$, and the free amino acid was extracted in the form of a clear supernatant which was used for spectrophotometric estimation. The volume of supernatant was raised to $10 \mathrm{ml}$ with aqueous $50 \%$ ethanol. To $1 \mathrm{ml}$ of the supernatant, $2 \mathrm{ml}$ of $2 \%$ Ninhydrin (w/v in dehydrated alcohol) was added. The mixture was kept on a water bath at $75 \pm 2{ }^{\circ} \mathrm{C}$ for $10 \mathrm{~min}$, and after cooling, aqueous alcohol (1:1) was added to make up the volume to $3 \mathrm{ml}$. The absorbance was measured at $570 \mathrm{~nm}$ on a spectrophotometer. Glycine was used as a standard.

\section{Determination of fat content}

The fat content was determined [32]. Two grams of the sample was taken in dried test tubes, and petroleum ether was added on that and allowed to stand for $16 \mathrm{~h}$. After $16 \mathrm{~h}$, the petroleum ether was evaporated to dryness and weights the flask before after for fat.

\section{Estimation of total crude fiber}

Crude fiber of the tuber samples was estimated [32]. One gram of dried leaf sample was subjected to acid and subsequent alkali digestion for degradation of native cellulose and lignin. The residue obtained after final filtration was weighed, incinerated, cooled, and weighed again. The loss in weight gives the crude fiber contents.

\section{Determination of ascorbic acid}

For determination of ascorbic acid content in the tubers, [33] method was employed. Five grams of the sample was weighed into a bottle containing $100 \mathrm{ml}$ of ethylenediaminetetraacetic acid (EDTA)/tricarboxylic acid (TCA) $(2: 1 \mathrm{v} / \mathrm{v})$ extraction solution. The mixture was shaken vigorously for $30 \mathrm{~min}$. The solution was transferred into a centrifuge tube, and centrifugation was done at 3000 $\mathrm{rpm}$ for $20 \mathrm{~min}$. Then, the preparation was transferred to a $100-\mathrm{ml}$ volumetric flask and $1 \%$ starch indicator was added followed by titration with $20 \%$ copper sulfate $\left(\mathrm{CuSO}_{4}\right)$ and waited until the dark color was developed.

\section{Determination of riboflavin}

For the determination of tubers riboflavin content, $5 \mathrm{~g}$ of the sample was extracted with $100 \mathrm{ml}$ of $50 \%$ ethanol and shaken for $1 \mathrm{~h}$ followed by the filtration into $100 \mathrm{ml}$ flask. From this preparation, $10 \mathrm{ml}$ of the extract was pipetted into $50 \mathrm{ml}$ volumetric flask and $10 \mathrm{ml}$ of each $5 \%$ 
potassium permanganate, and $30 \% \mathrm{H}_{2} \mathrm{O}_{2}$ was added subsequently. This preparation was taken to a hot water bath for $30 \mathrm{~min}$. This was followed by the addition of 2 $\mathrm{ml}$ of $40 \%$ sodium sulfate. The volume was made up to $50 \mathrm{ml}$ and the absorbance measured at $510 \mathrm{~nm}$ [34].

\section{Determination of thiamine}

Five grams of the tuber sample was homogenized with $50 \mathrm{ml} \mathrm{10 \%} \mathrm{ethanolic} \mathrm{sodium} \mathrm{hydroxide} \mathrm{and} \mathrm{filtered} \mathrm{into}$ a 100-ml conical flask. Ten milliliters of the filtrate was pipetted, and the color was developed by the addition of $10 \mathrm{ml} 1 \%$ potassium dichromate; the absorbance was measured at $360 \mathrm{~nm}$ [34].

\section{Determination of alkaloids}

The alkaloid content was determined [35]. For this, $5 \mathrm{~g}$ of the sample was weighed and taken into a $250-\mathrm{ml}$ beaker containing $200 \mathrm{ml}$ of $10 \%$ acetic acid in ethanol and allowed to stand for $4 \mathrm{~h}$. This preparation was concentrated on a water bath to one quarter of the original volume. Concentrated ammonium hydroxide was added drop wise to the extract until the precipitation was completed. The precipitate was collected and washed with dilute ammonium hydroxide followed by filtration. The residue was dried and weighed.

\section{Determination of total phenols}

Total phenol was determined [36]. $200 \mathrm{mg}$ of sample was crushed in $10 \%$ methanol and centrifuged for 20 min at $5000 \mathrm{rpm} .1 \mathrm{ml}$ supernatant was taken and $1 \mathrm{ml}$ Folin Ciocalteu reagent was added flowed by the incubation for $3 \mathrm{~min}$ at room temperature. Then, $1 \mathrm{ml}$ of saturated $20 \% \mathrm{Na}_{2} \mathrm{CO}_{3}$ was added and kept in a water bath for $1 \mathrm{~min}$. The absorbance was measured at $725 \mathrm{~nm}$. Gallic acid was used as a standard.

\section{Determination of flavonoids}

The flavonoid content was estimated [37]. $0.5 \mathrm{ml}$ of test sample solution in methanol $(5 \mathrm{mg} / 100 \mathrm{ml})$ was mixed with $2 \mathrm{ml}$ of distilled water and $150 \mu \mathrm{l}$ of $5 \%$ sodium nitrate. After $6 \mathrm{~min}, 150 \mu \mathrm{l}$ of $10 \%$ aluminum chloride and $2 \mathrm{ml}$ of $1 \mathrm{M}$ sodium hydroxide was added and left at room temperature for $15 \mathrm{~min}$. The absorbance of the mixtures was measured at $510 \mathrm{~nm}$. Catechin was used as a standard.

\section{Determination of saponin}

Saponin was determined [38]. Twenty grams of tuber samples were put into conical flasks containing $100 \mathrm{ml}$ of $20 \%$ aqueous ethanol and heated at $55^{\circ} \mathrm{C}$ for $4 \mathrm{~h}$. The mixture was then filtered and re-extracted with another $200 \mathrm{ml} 20 \%$ ethanol. The combined extracts were reduced to $40 \mathrm{ml}$ in a water bath. The concentrate was transferred into a 250-ml separating funnel containing
$20 \mathrm{ml}$ of diethyl ether and shaken vigorously. The aqueous layer was recovered and further purification was done in $60 \mathrm{ml}$ of $\mathrm{n}$-butanol. The preparation was washed twice with $10 \mathrm{ml}$ of $5 \%$ aqueous sodium chloride. The remaining solution was heated in a water bath followed by the evaporation of the samples. The residue was dried and weighed.

\section{Determination of tannin}

The tannin content was estimated [39]. Five hundred milligrams of powdered sample was dissolved in $50 \mathrm{ml}$ of distilled water and shaken for about $1 \mathrm{~h}$ in a mechanical shaker. This was filtered through cheese clothes into a 50-ml volumetric flask and made up to the mark. Then, $5 \mathrm{ml}$ of the filtered was pipette out into a test tube and mixed with $2 \mathrm{ml}$ of $0.1 \mathrm{M} \mathrm{FeCl}_{3}$ in $0.1 \mathrm{~N} \mathrm{HCl}$ and $0.008 \mathrm{M}$ potassium ferrocyanide. The absorbance was measured at $760 \mathrm{~nm}$ within $10 \mathrm{~min}$. Tannic acid was used as a standard.

\section{DPPH radical scavenging activity}

The free radical scavenging activities of methanol extract of all the samples were evaluated by 1,1-diphenyl-2picryl-hydrazyl (DPPH) method [40]. Different concentrations of methanol extracts $(30,60,120,240,480,600$, $720,840,960 \mu \mathrm{g} / \mathrm{ml}$ of the sample) were mixed with $300 \mu \mathrm{DPPH}(0.02 \mathrm{mM})$. The absorbance was measured at $517 \mathrm{~nm}$ using a UV-VIS double beam spectrophotometer (Dynamica, DB-20and SL. No. - 6622065) after 30 min of incubation at dark. Ascorbic acid was used as the reference sample. Scavenging of DPPH was calculated by using the formula:

$$
\begin{aligned}
& \text { DPPH scavenging activity (\% of inhibition) } \\
& \quad=\left(A_{0}-A_{1}\right) \times 100 / A_{0}
\end{aligned}
$$

where $A_{0}$ is the absorbance of the control reaction and $A_{1}$ is the absorbance of the sample.

\section{Evaluation of antimicrobial activity}

The antibacterial potentiality of the tubers of male and female tubers was determined by the agar well diffusion method. Streptomycin and dimethyl sulfoxide (DMSO) were used as positive and negative controls for antibacterial study. The results were recorded by using a ruler with a sliding caliper [41], and the inhibition zone was expressed in millimeters. The anti-fungal activity of the compounds was determined by the agar well diffusion method.

\section{Data analysis}

Each of the analysis was performed in triplicate and expressed as mean \pm SD. Antioxidant activity was determined and inhibition concentration $\left(\mathrm{IC}_{50}\right)$ values were 
calculated using the linear regression curve in Microsoft Excel 2007. All the statistical analysis was done by using Microsoft Excel 2007.

\section{Results}

Nutritional aspects

\section{Moisture content}

Female tubers of most of the Dioscorea species show higher moisture content (MC) compared to male ones. Maximum and minimum MC was recorded in female and male tubers of D. alata. The MC varied significantly among the tubers of the female and male plant of $D$. alata $(P<0.01)$ and D. oppositifolia and D. pubera $(P<$ $0.05)$. No significant difference was observed in the male and female tubers of $D$. hamiltonii and $D$. wallichii.

\section{Total protein}

The total protein (TP) content of the tubers ranged between $3.15 \pm 0.05$ and $13.25 \pm 0.22 \mathrm{mg} / \mathrm{gm}$ fresh weight. Maximum and minimum TP content was recorded in the tuber of the male plant of D. pubera and D. oppositifolia, respectively. The total protein content differs significantly among the tuber of male and female plant of $D$. oppositifolia and D. pubera $(P<0.001)$, D. alata $(P<0.01), D$. hamiltonii $(P<0.05)$.

\section{Total carbohydrate}

Maximum and minimum total carbohydrate (TC) content was observed in female tubers of $D$. hamiltonii and male tubers of $D$. wallichii, respectively. Significant differences were observed in the TC content of male and female tuber of D. alata, D. oppositifolia, D. pubera $(P<$ $0.05)$, and $D$. wallichii $(P<0.01)$.

\section{Total soluble sugar}

Maximum and minimum total soluble sugar (TSS) content was recorded in female tubers of D. glabra and $D$. oppositifolia, respectively. No significant differences existed between the male and female tuber of $D$. hamiltonii, D. pubera, D. oppositifolia, and D. glabra while only $D$. alata showed significant difference $(P<0.01)$.

\section{Total free amino acid}

Total free amino acids (TFA) do not differ significantly among the male and female Dioscorea tubers. Only the male and female tubers of $D$. wallichii showed a significant $(P<0.05)$ difference. Maximum and minimum TFA was recorded in the tubers of the female plant of D. hamiltonii and D. pubera, respectively.

\section{Total crude fiber}

The total crude fiber (TCF) content significantly differed $(P<0.05)$ among the tuber of male and female plant of
D. hamiltonii and D. wallichii. However, no significant variation was observed in the male and female plant tuber of D. alata, D. oppositifolia, and D. pubera. The maximum amount of TCF was recorded in the female tuber of $D$. alata and minimum in the male tuber of $D$. glabra.

\section{Total fat}

The total fat (TF) content varied significantly among the male and female tuber of $D$. oppositifolia $(P<0.01)$ and D. wallichii $(P<0.05)$. No significant variation was observed in the tuber of male and female plant of D. alata, D. pubera, and D. hamiltonii. Maximum and minimum TF was recorded in female tuber of D. alata and male tuber of $D$. hamiltonii, respectively.

\section{Vitamins}

Among the studied Dioscorea species, the maximum ascorbic acid ( $\mathrm{Aa}$ ) content was observed in the female tuber of $D$. oppositifolia while minimum in male tuber of $D$. wallichii. No significant variation was observed among the male and female tuber of Dioscorea. Riboflavin (Rf) content in the tuber of male and female Dioscorea species showed no significant difference except $D$. oppositifolia $(P$ $<0.05)$. Maximum and minimum $\mathrm{Rf}$ content was recorded in female tuber of D. alata and male tuber of D. oppositifolia, respectively. In tuber thiamine (Th) content, $D$. pubera and $D$. wallichii showed significant variation $(P<0.05)$ between their male and female plants. Female tuber of $D$. alata showed the maximum Th content while male tuber of $D$. pubera showed the least.

\section{Anti-nutritional aspects \\ Total alkaloid}

Total alkaloid (TA) content in both male and female tubers of $D$. alata and D. pubera was significant $(P<$ $0.05)$, whereas no significant difference was observed between the male and female tubers of other species. Maximum and minimum TA content was recorded from the tubers of female D. hamiltonii and D. oppositifolia, respectively.

\section{Total phenol}

The total phenol (TPH) content of male and female tubers of two species viz. D. wallichii and D. oppositifolia showed highly significant $(P<0.001)$ variation. Maximum phenol content was recorded in D. oppositifolia female tuber while the female plant of $D$. wallichii showed the least.

\section{Total flavonoid}

The total flavonoid (TF) contents of tubers of male and female plant of $D$. alata, D. hamiltonii $(P<0.05)$, and $D$. wallichii $(P<0.01)$ varied significantly. The maximum 
TF was recorded in female tuber of D. oppositifolia, whereas the least was recorded in the male tuber of male and female D. hamiltonii, D. wallichii, and D. pubera plants reflected no significant difference.

\section{Total tannin}

Maximum total tannin (TT) content recorded in the male tuber of D. oppositifolia and the least was observed in the male tuber of $D$. hamiltonii. TT in the tuber of male and female exhibited significant differences except $D$. pubera and D. wallichii. TT differs significantly in the tubers of male and female plants of D. oppositifolia, $D$. wallichii, D. alata, and D. hamiltonii $(P<0.001)$.

\section{Total saponin}

Tubers of male and female plants of $D$. alata showed a significant $(P<0.05)$ difference in total saponin (TS) content. Maximum and minimum TS were recorded from tubers of female $D$. hamiltonii and male tuber of D. oppositifolia, respectively.

\section{DPPH radical scavenging activity}

The methanolic extracts of tubers male and female Dioscorea plants possessed potent DPPH radical scavenging activity in terms of percentage of inhibition. Antioxidant activity varies significantly among the male and female tuber of the same species. Maximum and minimum antioxidant activity was recorded in the tubers of female $D$. oppositifolia and male D. hamiltonii, respectively. This study also revealed that tubers of the female plant tubers exhibit potent antioxidant activity compared to male counterpart. No significant difference was observed in the tubers of male and female $D$. alata.

\section{Antimicrobial activity}

Antimicrobial activity of methanol extracts of male and female tuber of five Dioscorea species were screened against four pathogenic bacteria and two pathogenic fungi. The antimicrobial activity was determined in terms of the inhibition zone around the respective microbial colonies. Maximum microbial activity against all the pathogenic bacteria and fungi was recorded in the methanolic extracts of both male and female tubers of D. pubera. Male and female tubers D. oppositifolia showed proficient activity against the selected fungal strains and bacterium Klebsiella pneumoniae. D. hamiltonii male and female tubers exhibited noticeable antibacterial activity against Streptococcus pneumoniae. The female tubers of $D$. wallichii showed strong activity than their male counterpart.

\section{Discussion}

This present study has been carried out to evaluate the sex-specific variation of nutrients and antinutrient aspects along with their antioxidant and antimicrobial potentiality of Dioscorea tubers (Tables 2, 3, 4, 5 and 6). A total of five edible species were selected for this present study out of which all are dioecious, i.e., male and female plants are developed separately. The tubers of superior crop yam [42] assist nutrients three times more than the most important food crops like cassava and sweet potato [43]. A considerable amount of research work has been carried out throughout the world but none of them are emphasizing the sex-specific evaluation of phytochemical constituents and biological efficacy of Dioscorea spp. The results obtained from the study revealed that significant differences existed between the most of the male and female tubers in terms of nutrient, vitamins,

Table 2 Nutritional status of different sexes of Dioscorea species found in Tripura

\begin{tabular}{|c|c|c|c|c|c|c|c|c|c|c|c|c|c|c|}
\hline \multirow{3}{*}{$\begin{array}{l}\text { Name of the } \\
\text { plants }\end{array}$} & \multicolumn{14}{|c|}{ Proximate composition } \\
\hline & \multicolumn{2}{|c|}{$\begin{array}{l}\text { Moisture content } \\
(\%)\end{array}$} & \multicolumn{2}{|c|}{$\begin{array}{l}\text { Total protein } \\
\text { (mg/gm) }\end{array}$} & \multicolumn{2}{|c|}{$\begin{array}{l}\text { Carbohydrate (mg/ } \\
\text { gm) }\end{array}$} & \multicolumn{2}{|c|}{$\begin{array}{l}\text { Soluble sugar } \\
\text { (mg/gm) }\end{array}$} & \multicolumn{2}{|c|}{$\begin{array}{l}\text { Free amino acid } \\
\text { (mg/gm) }\end{array}$} & \multicolumn{2}{|c|}{ Crude fiber (\%) } & \multicolumn{2}{|c|}{ Total fat (\%) } \\
\hline & M & $\mathrm{F}$ & M & $\mathrm{F}$ & M & $\mathrm{F}$ & M & $\mathrm{F}$ & M & $\mathrm{F}$ & M & $\mathrm{F}$ & M & $\mathrm{F}$ \\
\hline $\begin{array}{l}\text { Dioscorea } \\
\text { alata }\end{array}$ & $\begin{array}{l}58.21 \pm \\
0.91\end{array}$ & $\begin{array}{l}77.97 \pm \\
1.72^{\mathrm{b}}\end{array}$ & $\begin{array}{l}4.22 \pm \\
0.30\end{array}$ & $\begin{array}{l}5.93 \pm \\
0.22^{\mathrm{b}}\end{array}$ & $\begin{array}{l}180.25 \\
\pm 2.81\end{array}$ & $\begin{array}{l}211.92 \pm \\
5.92^{c}\end{array}$ & $\begin{array}{l}18.54 \pm \\
0.44\end{array}$ & $\begin{array}{l}20.91 \pm \\
0.92^{\mathrm{b}}\end{array}$ & $\begin{array}{l}1.68 \pm \\
0.14\end{array}$ & $\begin{array}{l}1.72 \pm \\
0.12^{\#}\end{array}$ & $\begin{array}{l}2.74 \pm \\
0.14\end{array}$ & $\begin{array}{l}3.00 \pm \\
0.16^{\#}\end{array}$ & $\begin{array}{l}1.66 \pm \\
0.14\end{array}$ & $\begin{array}{l}1.97 \pm \\
0.12^{\#}\end{array}$ \\
\hline $\begin{array}{l}\text { Dioscorea } \\
\text { hamiltonii }\end{array}$ & $\begin{array}{l}66.72 \pm \\
1.94\end{array}$ & $\begin{array}{l}71.44 \pm \\
0.92^{\#}\end{array}$ & $\begin{array}{l}3.34 \pm \\
0.42\end{array}$ & $\begin{array}{l}4.21 \pm \\
0.32^{c}\end{array}$ & $\begin{array}{l}239.93 \\
\pm 4.54\end{array}$ & $\begin{array}{l}254.95 \pm \\
6.54^{\#}\end{array}$ & $\begin{array}{l}20.81 \pm \\
0.31\end{array}$ & $\begin{array}{l}22.28 \pm \\
0.42^{\#}\end{array}$ & $\begin{array}{l}1.64 \pm \\
0.13\end{array}$ & $\begin{array}{l}1.87 \pm \\
0.14^{\#}\end{array}$ & $\begin{array}{l}1.82 \pm \\
0.18\end{array}$ & $\begin{array}{l}2.23 \pm \\
0.14^{c}\end{array}$ & $\begin{array}{l}0.98 \pm \\
0.12\end{array}$ & $\begin{array}{l}1.19 \pm \\
0.14^{\#}\end{array}$ \\
\hline $\begin{array}{l}\text { Dioscorea } \\
\text { oppositifolia }\end{array}$ & $\begin{array}{l}66.94 \pm \\
0.41\end{array}$ & $\begin{array}{l}71.18 \pm \\
0.81^{c}\end{array}$ & $\begin{array}{l}3.19 \pm \\
0.14\end{array}$ & $\begin{array}{l}5.73 \pm \\
0.17^{\mathrm{a}}\end{array}$ & $\begin{array}{l}143.97 \\
\pm 5.01\end{array}$ & $\begin{array}{l}173.86 \pm \\
5.60^{c}\end{array}$ & $\begin{array}{l}14.02 \pm \\
0.22\end{array}$ & $\begin{array}{l}13.37 \pm \\
0.34^{\#}\end{array}$ & $\begin{array}{l}0.98 \pm \\
0.18\end{array}$ & $\begin{array}{l}1.28 \pm \\
0.16^{\#}\end{array}$ & $\begin{array}{l}2.24 \pm \\
0.23\end{array}$ & $\begin{array}{l}2.87 \pm \\
0.34^{\#}\end{array}$ & $\begin{array}{l}1.58 \pm \\
0.14\end{array}$ & $\begin{array}{l}1.24 \pm \\
0.16^{\mathrm{b}}\end{array}$ \\
\hline $\begin{array}{l}\text { Dioscorea } \\
\text { pubera }\end{array}$ & $\begin{array}{l}66.43 \pm \\
1.35\end{array}$ & $\begin{array}{l}75.72 \pm \\
1.24^{c}\end{array}$ & $\begin{array}{l}13.21 \pm \\
0.22\end{array}$ & $\begin{array}{l}9.67 \pm \\
0.22^{\mathrm{a}}\end{array}$ & $\begin{array}{l}136.92 \\
\pm 3.47\end{array}$ & $\begin{array}{l}158.01 \pm \\
6.53^{c}\end{array}$ & $\begin{array}{l}23.54 \pm \\
0.24\end{array}$ & $\begin{array}{l}28.20 \pm \\
1.92^{\#}\end{array}$ & $\begin{array}{l}0.94 \pm \\
0.15\end{array}$ & $\begin{array}{l}1.05 \pm \\
0.19^{\#}\end{array}$ & $\begin{array}{l}1.48 \pm \\
0.13\end{array}$ & $\begin{array}{l}2.18 \pm \\
0.23^{\#}\end{array}$ & $\begin{array}{l}1.18 \pm \\
0.12\end{array}$ & $\begin{array}{l}1.28 \pm \\
0.18^{\#}\end{array}$ \\
\hline $\begin{array}{l}\text { Dioscorea } \\
\text { wallichii }\end{array}$ & $\begin{array}{l}68.62 \pm \\
1.28\end{array}$ & $\begin{array}{l}70.55 \pm \\
1.12^{\#}\end{array}$ & $\begin{array}{l}7.04 \pm \\
0.32\end{array}$ & $\begin{array}{l}9.84 \pm \\
0.30^{c}\end{array}$ & $\begin{array}{l}114.92 \\
\pm 3.33\end{array}$ & $\begin{array}{l}136.73 \pm \\
4.72^{b}\end{array}$ & $\begin{array}{l}27.34 \pm \\
1.57\end{array}$ & $\begin{array}{l}31.46 \pm \\
1.58^{\#}\end{array}$ & $\begin{array}{l}1.41 \pm \\
0.10\end{array}$ & $\begin{array}{l}1.63 \pm \\
0.14^{C}\end{array}$ & $\begin{array}{l}1.23 \pm \\
0.19\end{array}$ & $\begin{array}{l}1.58 \pm \\
0.14^{c}\end{array}$ & $\begin{array}{l}1.14 \pm \\
0.12\end{array}$ & $\begin{array}{l}1.42 \pm \\
0.14^{c}\end{array}$ \\
\hline
\end{tabular}

$M$ male, $F$ female, significant level $5 \%$

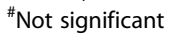

$a^{a}<0.001$

$\mathrm{b}^{\mathrm{b}}<0.01$

${ }^{c}<0.05$ 
Table 3 Vitamin contents of different sexes of Dioscorea species found in Tripura

\begin{tabular}{|c|c|c|c|c|c|c|}
\hline \multirow[t]{3}{*}{ Name of the plants } & \multicolumn{6}{|c|}{ Vitamins (mg/g of the sample) } \\
\hline & \multicolumn{2}{|l|}{ Ascorbic acid } & \multicolumn{2}{|l|}{ Thiamine } & \multicolumn{2}{|l|}{ Riboflavin } \\
\hline & $\bar{M}$ & $\mathrm{~F}$ & $\bar{M}$ & $\mathrm{~F}$ & $\bar{M}$ & $\mathrm{~F}$ \\
\hline Dioscorea alata & $13.49 \pm 3.64$ & $18.26 \pm 1.37^{\#}$ & $1.14 \pm 0.16$ & $1.26 \pm 0.11^{\#}$ & $1.75 \pm 0.26$ & $1.87 \pm 0.2^{\#}$ \\
\hline Dioscorea hamiltonii & $10.31 \pm 2.75$ & $12.7 \pm 3.64^{\#}$ & $1.15 \pm 0.09$ & $1.03 \pm 0.16^{\#}$ & $0.82 \pm 0.07$ & $0.98 \pm 0.12^{\#}$ \\
\hline Dioscorea oppositifolia & $19.84 \pm 3.63$ & $26.19 \pm 2.38^{\#}$ & $0.94 \pm 0.14$ & $1.14 \pm 0.16^{\#}$ & $0.78 \pm 0.11$ & $1.14 \pm 0.08^{c}$ \\
\hline Dioscorea pubera & $14.29 \pm 2.38$ & $15.88 \pm 1.37^{\#}$ & $0.85 \pm 0.07$ & $0.99 \pm 0.11^{c}$ & $1.02 \pm 0.08$ & $0.94 \pm 0.14^{\#}$ \\
\hline Dioscorea wallichii & $9.52 \pm 2.38$ & $12.7 \pm 1.4^{\#}$ & $1.25 \pm 0.13$ & $1.11 \pm 0.12^{c}$ & $1.18 \pm 0.1$ & $1.13 \pm 0.24^{\#}$ \\
\hline
\end{tabular}

antinutrient, antioxidant, and antimicrobial efficacy. The possible reasons for these variations may be attributable to different factors such as genetic, climate, and environmental conditions [44-47]. In line with the earlier findings $[48,49]$, experimental results showed that a significant and positive correlation exists between the phenolic contents and antioxidant potentiality. The high antioxidant potentiality of Dioscorea tubers may be one of the key determinants of their inclusion in traditional folkloric medicine. Mittelstrass et al. [50] proclaimed that male and female plants differ in their metabotypes which may be attributable to herbivore preferences for gender [51-54] which in turn are correlated secondary metabolite contents. Higher amounts of phenols and antioxidants are connected with the defense strategies of plants $[55,56]$. The pinpointing findings of this present study are the sexspecific study of the nutrient, antinutrient, antioxidant, and antimicrobial activity which is lacking in earlier findings. The methanolic extracts of the female tubers have proficient antibacterial potentiality which is in congruence with the earlier finding [57]. Among the tested bacterial strains, gram-positive bacterium (Streptococcus pneumoniae) is more susceptible compared to the gram-negative bacteria which reaffirmed the earlier findings [58-60]. Moreover, among all the selected Dioscorea species, most of the tubers of female plants are superior compared to the male counterparts although they are residing at the same climatic conditions or ecosystems which were the reconfirmation of earlier findings although their studied samples are different [17-19]. To consign, a specific reason for the findings of this present study is may be due to the different physiological and reproductive adaptive responses of both the sexes irrespective of their occurrences in the same microclimate.

Table 4 Anti-nutritional status of male and female tubers of Dioscorea species found in Tripura

\begin{tabular}{|c|c|c|c|c|c|c|c|c|c|c|}
\hline \multirow[t]{3}{*}{ Name of the plant } & \multicolumn{10}{|c|}{ Antinutrient status } \\
\hline & \multicolumn{2}{|c|}{ Alkaloid (\%) } & \multicolumn{2}{|c|}{ Phenol (mg/gm) } & \multicolumn{2}{|c|}{ Flavonoid (mg/gm) } & \multicolumn{2}{|c|}{ Tannin (mg/gm) } & \multicolumn{2}{|c|}{ Saponin (\%) } \\
\hline & M & $\mathrm{F}$ & M & $\mathrm{F}$ & M & $\mathrm{F}$ & M & $\mathrm{F}$ & M & $\mathrm{F}$ \\
\hline Dioscorea alata & $\begin{array}{l}0.65 \pm \\
0.08\end{array}$ & $\begin{array}{l}1.05 \pm \\
0.07^{c}\end{array}$ & $\begin{array}{l}12.21 \pm \\
0.82\end{array}$ & $\begin{array}{l}17.53 \pm \\
1.30^{\mathrm{b}}\end{array}$ & $\begin{array}{l}14.80 \pm \\
0.69\end{array}$ & $9.17 \pm 0.3^{b}$ & $3.33 \pm 0.12$ & $\begin{array}{l}5.48 \pm \\
0.18^{\mathrm{b}}\end{array}$ & $\begin{array}{l}0.48 \pm \\
0.06\end{array}$ & $\begin{array}{l}0.93 \pm \\
0.17^{c}\end{array}$ \\
\hline Dioscorea hamiltonii & $\begin{array}{l}1.05 \pm \\
0.07\end{array}$ & $\begin{array}{l}1.21 \pm \\
0.11^{\#}\end{array}$ & $\begin{array}{l}41.40 \pm \\
2.94\end{array}$ & $\begin{array}{l}50.70 \pm \\
2.49^{\mathrm{a}}\end{array}$ & $\begin{array}{l}25.67 \pm \\
0.93\end{array}$ & $\begin{array}{l}36.67 \pm \\
0.99^{b}\end{array}$ & $\begin{array}{l}10.08 \pm \\
0.14\end{array}$ & $\begin{array}{l}6.25 \pm \\
0.02^{\mathrm{a}}\end{array}$ & $\begin{array}{l}0.95 \pm \\
0.14\end{array}$ & $\begin{array}{l}1.16 \pm \\
0.18^{\#}\end{array}$ \\
\hline $\begin{array}{l}\text { Dioscorea } \\
\text { oppositifolia }\end{array}$ & $\begin{array}{l}0.27 \pm \\
0.03\end{array}$ & $\begin{array}{l}0.41 \pm \\
0.04^{\#}\end{array}$ & $\begin{array}{l}11.03 \pm \\
0.60\end{array}$ & $\begin{array}{l}13.65 \pm \\
0.36^{c}\end{array}$ & $7.21 \pm 0.99$ & $\begin{array}{l}15.03 \pm \\
1.08^{c}\end{array}$ & $0.22 \pm 0.1$ & $\begin{array}{l}3.04 \pm \\
0.06^{\mathrm{a}}\end{array}$ & $\begin{array}{l}0.45 \pm \\
0.09\end{array}$ & $\begin{array}{l}0.81 \pm \\
0.15^{\#}\end{array}$ \\
\hline Dioscorea pubera & $\begin{array}{l}0.35 \pm \\
0.05\end{array}$ & $\begin{array}{l}0.33 \pm \\
0.05^{\#}\end{array}$ & $\begin{array}{l}31.76 \pm \\
0.21\end{array}$ & $21.83 \pm 2.5^{c}$ & $19.68 \pm 1$ & $22.17 \pm 0.2^{\#}$ & $1.45 \pm 0.16$ & $\begin{array}{l}1.05 \pm \\
0.22^{\#}\end{array}$ & $\begin{array}{l}0.88 \pm \\
0.23\end{array}$ & $\begin{array}{l}0.92 \pm \\
0.17^{\#}\end{array}$ \\
\hline Dioscorea wallichii & $\begin{array}{l}0.31 \pm \\
0.23\end{array}$ & $\begin{array}{l}0.52 \pm \\
0.06^{\#}\end{array}$ & $\begin{array}{l}10.73 \pm \\
0.25\end{array}$ & $9.73 \pm 0.28^{\#}$ & $20.6 \pm 0.6$ & $\begin{array}{l}26.00 \pm \\
2.14^{c}\end{array}$ & $1.28 \pm 0.19$ & $\begin{array}{l}2.11 \pm \\
0.21^{\#}\end{array}$ & $\begin{array}{l}0.91 \pm \\
0.09\end{array}$ & $\begin{array}{l}1.07 \pm \\
0.13^{\#}\end{array}$ \\
\hline
\end{tabular}

$M$ male, $F$ female, significant level $5 \%$

\#Not significant

${ }^{a}<0.001$

$\mathrm{b}<0.01$

${ }^{c}<0.05$ 
Table 5 Antimicrobial activity of male and female tubers of Dioscorea species found in Tripura

\begin{tabular}{|c|c|c|c|c|c|c|c|}
\hline \multirow{3}{*}{$\begin{array}{l}\text { Name of the } \\
\text { plants }\end{array}$} & \multicolumn{7}{|c|}{ Antimicrobial activity ( inhibition zone in mm) } \\
\hline & \multirow[t]{2}{*}{ Sexes } & \multicolumn{4}{|l|}{ Bacterial strain } & \multicolumn{2}{|l|}{ Fungal strain } \\
\hline & & $\begin{array}{l}\text { Klebsiella } \\
\text { pneumoniae (MTCC- } \\
\text { 3384) }\end{array}$ & $\begin{array}{l}\text { Streptococcus } \\
\text { pneumoniae (MTCC- } \\
655)\end{array}$ & $\begin{array}{l}\text { Escherichia coli } \\
\text { (MTCC-443) }\end{array}$ & $\begin{array}{l}\text { Shigella } \\
\text { dysenteriae } \\
\text { (MTCC-227) }\end{array}$ & $\begin{array}{l}\text { Candida } \\
\text { albicans (MTCC- } \\
\text { 227) }\end{array}$ & $\begin{array}{l}\text { Candida tropicalis } \\
\text { (Agartala medical } \\
\text { college) }\end{array}$ \\
\hline \multirow{2}{*}{$\begin{array}{l}\text { Dioscorea } \\
\text { alata }\end{array}$} & M & - & - & - & - & - & $7.8 \pm 0.20$ \\
\hline & $\mathbf{F}$ & - & $8.76 \pm 0.25$ & - & - & $7.66 \pm 0.35$ & - \\
\hline \multirow{2}{*}{$\begin{array}{l}\text { Dioscorea } \\
\text { hamiltonii }\end{array}$} & M & - & $11.80 \pm 1.05$ & - & - & $6.93 \pm 0.15$ & $7.23 \pm 0.32$ \\
\hline & $F$ & - & $12.13 \pm 0.75$ & - & $8.70 \pm 0.36$ & - & - \\
\hline \multirow{2}{*}{$\begin{array}{l}\text { Dioscorea } \\
\text { oppositifolia }\end{array}$} & M & $10.70 \pm 0.36$ & - & $9.36 \pm 0.55$ & $8.23 \pm 0.25$ & $7.83 \pm 0.15$ & $7.53 \pm 0.50$ \\
\hline & $\mathbf{F}$ & $9.46 \pm 0.50$ & - & - & $11.0 \pm 0.40$ & $7.96 \pm 0.15$ & $9.83 \pm 0.15$ \\
\hline \multirow{2}{*}{$\begin{array}{l}\text { Dioscorea } \\
\text { pubera }\end{array}$} & M & $9.43 \pm 0.51$ & $11.76 \pm 0.68$ & $10.53 \pm 0.50$ & $10.86 \pm 0.23$ & $8.56 \pm 0.40$ & $6.83 \pm 0.20$ \\
\hline & $F$ & $10.56 \pm 0.40$ & $11.76 \pm 0.68$ & $9.8 \pm 0.2$ & $8.60 \pm 0.52$ & $10.80 \pm 0.20$ & $8.93 \pm 0.20$ \\
\hline \multirow{2}{*}{$\begin{array}{l}\text { Dioscorea } \\
\text { wallichii }\end{array}$} & $M$ & $8.60 \pm 0.40$ & - & - & $7.83 \pm 0.20$ & - & $8.80 \pm 0.20$ \\
\hline & $F$ & $9.30 \pm 0.26$ & $8.76 \pm 0.20$ & $8.86 \pm 0.32$ & $9.96 \pm 0.15$ & $9.83 \pm 0.28$ & $4.23 \pm 0.25$ \\
\hline
\end{tabular}

$M$ male, $F$ female

\section{Conclusion}

This study is a precursive effort to estimate the sexspecific variations in the phytochemical constituents and biological activities of Dioscorea tubers. Further researches are needed to be carried out by incorporating modern scientific tools to underpin the actual physiological mechanism associated with these variations which may be helpful in the early delimitation of sexes. This study also ensures that female Dioscorea tubers are the reservoir of biological compounds compared to the male counterpart which may be able to draw the attention of nutraceutical industries leading to the discovery of noble drugs.

Table 6 Inhibitory concentration of male and female tubers of Dioscorea species found in Tripura

\begin{tabular}{lll}
\hline Plant name & Sex & $\mathrm{IC}_{50}(\mu \mathrm{g} / \mathrm{ml})$ \\
\hline Dioscorea alata & Male & 232.58 \\
Dioscorea alata & Female & 284.71 \\
Dioscorea hamiltonii & Male & 648.86 \\
Dioscorea hamiltonii & Female & 340.50 \\
Dioscorea oppositifolia & Male & 25.17 \\
Dioscorea oppositifolia & Female & 18.98 \\
Dioscorea pubera & Male & 313.58 \\
Dioscorea pubera & Female & 209.02 \\
Dioscorea wallichii & Male & 234.85 \\
Dioscorea wallichii & Female & 267.50 \\
Ascorbic acid (standard) & & 8.03 \\
\hline
\end{tabular}

\section{Abbreviations}

m asl: Height above sea level; SD: Standard deviation; MC: Moisture content; TP: Total protein; TC: Total carbohydrate; TSS: Total soluble sugar; TFA: Total free amino acids; TF: Total fat; TCF: Total crude fiber; Aa: Ascorbic acid; Th: Thiamine; Rf: Riboflavin; TA: Total alkaloid; TPH: Total phenol; TF: Total flavonoid; TT: Total tannin; TS: Total saponin

\section{Acknowledgements}

The authors are thankful to the Head of the Department of Forestry and Biodiversity for providing the laboratory facilities to carry out the work. The authors are thankful to Dr. Bipin Kumar Sarma for providing the microbial strains to study the antimicrobial activity.

\section{Authors' contributions}

$\mathrm{CP}$ and $\mathrm{BD}$ designed the manuscript. $C P, A D$, and $\mathrm{SG}$ carried out the experimental work. $C P$ and $K C$ contributed to the analysis of the data. $C P$, $\mathrm{KC}$, and $\mathrm{AB}$ wrote the manuscript. All authors read and approved the final manuscript

\section{Funding}

None

Availability of data and materials

All data and materials are available upon request.

Ethics approval and consent to participate

Not applicable

Consent for publication

Not applicable

\section{Competing interests}

The authors declare that they have no competing interests.

\section{Author details}

'Plant Diversity and Forest Biotechnology Laboratory, Department of Forestry and Biodiversity, Tripura University, Suryamaninagar, Agartala, Tripura 799022, India. ${ }^{2}$ Department of Botany, Tripura University, Suryamaninagar, Agartala, Tripura 799022, India. ${ }^{3}$ Department of Microbiology, Tripura University, Suryamaninagar, Agartala, Tripura 799022, India. 
Received: 4 June 2020 Accepted: 12 August 2020 Published online: 26 September 2020

\section{References}

1. Burkill $I H$ (1960) Organography and evolution of Dioscoreaceae, the family of yams. J Linnean Soc (Bot) 56(367):319-412

2. Ayensu ES (1972) Anatomy of the monocotyledons. Vol. VI. Dioscoreales, Oxford Press, Oxford. 182

3. Mulualem T, Mekbib F, Hussein S, Gebre E (2018) Analysis of biochemical composition of yams (Dioscorea spp.). Landraces from Southwest Ethiopia, Agrotech7:177. https://doi.org/10.4172/2168-9881.1000177

4. Zhang Z, Wang X, Liu C, Li J (2016) The degradation, antioxidant and antimutagenic activity of the mucilage polysaccharide from Dioscorea opposita. Carbohydr Polym. 150:227-231

5. Cui H, Li T, Wang L, Su Y, Xian CJ (2016) Dioscorea bulbifera polysaccharide and cyclophosphamide combination enhance anti-cervical cancer effect and attenuates immunosuppression and oxidative stress in mice. Sci Rep $6(1): 1-9$

6. Liu Y, Li H, Fan Y, Man S, Liu Z, Gao W, Wang T (2016) Antioxidant and antitumor activities of the extracts from Chinese yam (Dioscorea opposite Thunb.) flesh and peel and the effective compounds. J Food Sci 81(6):15531564

7. Kumar S, Das G, Shin HS, Patra JK (2017) Dioscorea spp. (A Wild Edible Tuber): a study on its ethnopharmacological potential and traditional use by the local people of Similipal Biosphere Reserve, India. Front Pharmacol 8(52):1-17

8. Coursey DG (1967) Yams: an account of the nature, origins, cultivation and utilisation of the useful member of the Dioscoreaceae. Longmans, London

9. Price EJ, Bhattacharjee R, Lopez-Montes A, Paul DF (2017) Metabolite profiling of yam (Dioscorea spp.) accessions for use in crop improvement programmes. Metabolomics 13(144):1-12

10. Kim JK, Park SU (2018) An update on the biological and pharmacological activities of diosgenin. EXCLI J 17:24-28

11. Djerassi C, Rosenkranz G, Pataki J, Kaufmann S (1952) Steroids, XXVII. Synthesis of allopregnane-3 , 11 beta, 17-, 20 , 21-pentol from cortisone and diosgenin. J Biol Chem. 194:115-118

12. Renner SS, Ricklefs RE (1995) Dioecy and its correlates in the flowering plants. Amer J Bot 82:596-606

13. Negbi M (1995) Male and female in Theophrastus's botanical works. J Hist Biol 28:317-322

14. Kleps RA, Myers TC, Lipcius RN, TO H (2007) A sex-specific metabolite identified in a marine invertebrate utilizing phosphorus-31 nuclear magnetic resonance. PLoS One 2(8):e780

15. Bajpai V, Pandey R, Negi MPS, Bindu KH, Kumar N, Kumar B (2012) Characteristic differences in metabolite profile in male and female plants of dioecious Piper betle L. J Biosci 37:1061-1066

16. Simpson BS (2013) Dioecy in plants - is it an important factor for phytochemists to consider. Planta Med 79:613-615

17. Tripathi S, Singh N, Shakya S, Dangi A, Bhattacharya SM, Dube A, Kumar N (2006) Landrace/gender based differences in phenol and thiocyanate contents and biological activity in Piper betle L. Curr Sci 91:746-749

18. Bajpai V, Singh A, Chandra P, Negi MPS, Kumar N, Kumar B (2015) Analysis of phytochemical variations in dioecious Tinospora cordifolia stems using HPLC/QTOF MS/MS and UPLC/QqQLIT-MS/MS. Phytochem Anal 27(2):92-99

19. Hussain SZ, Ahmed I (2019) Quantitative phytochemical screening of male and female tree leaves of Carica Papaya Linn. IOSR J Pharm 9(11):1-5

20. Nakajima G (1937a) Cytological studies in some flowering plants, with special references to the sex chromosomes. Cytologia 12:262-270

21. Ramachandran K (1962) Studies on the cytology and sex determination of the Dioscoreaceae. J Indian Bot Soc 41:93-98

22. Smith RW (1937) Notes on the cytology and distribution of the Dioscoreaceae. Bull Torr Bot Club 64:189-197

23. Meurman O (1925) The chromosomal behaviour of some dioecious plants and their relatives with special reference to the sex chromosome. Soc Sci Fenn Comm Biol 2:1-105

24. Martin FW (1966) Sex ratio and sex determination in Dioscorea. J Heredity 57(3):95-99

25. Ortiz S (1963) Chromosome numbers and behaviour in some species of Dioscorea. Cytologia 28:96-101

26. Deb DB (1983) The Flora of Tripura state. Vol.2. Today \& Tomorrows: Printers and Publishers New Delhi; pp. 417 - 422
27. Paul C, Debnath A, Debnath B (2014) Dioscorea oppositifolia Linnaeus (Dioscoreaceae) - a new distributional record for Tripura, India. Pleione 8(1): 184-187

28. Paul C, Debnath A, Chanda R, Debnath B (2017) Taxonomical note, new distributional record and traditional use for Dioscorea wallichii Hook. $\mathrm{f}$. (Dioscoreaceae) of Tripura, North-East India. Annals Plant Sci 6(12):1868-1871

29. Hedge JE, Hofreiter BT (1962) (Eds.) Whistler R. L and Be Miller, J.N.), Academic Press, New York. In: Carbohydrate Chemistry. p.17

30. Lowry OH, Rosenbrough NJ, Farr AL, Randoll RJ (1951) Estimation of protein with the folin-phenol reagent. J Biolog Chem 193:265-275

31. Yemm EW, Cocking EC (1955) The determination of amino-acids with ninhydrin. Analyst 80:209-213

32. AOAC (1960) Official methods of analysis.9th ed. Association of Official Agricultural Chemists. Washington, D. C.

33. Barakat MZ, Shahab SK, Darwin N, Zahemy El (1993) Determination of ascorbic acid from plants. Anal Biochem 53:225-245

34. Okwu DE, Josiah C (2006) Evaluation of the chemical composition of two Nigerian medicinal plants. Afr J Biotech 5:357-351

35. Harborne JB (1973) Phytochemical methods London Chapman and Hall, Ltd. pp 49-188

36. Ferreira ICFR, Baptista P, Vilas-Boas M, Barros L (2007) Free-radical scavenging capacity and reducing power of wild edible mushrooms from northeast Portugal: individual cap and stipe activity. Food Chem 100:1511-1516

37. Zhishen J, Mengcheng T, Jianming W (1999) The determination of flavonoid contents in mulberry and their scavenging effects on superoxide radicals. Food Chem 64:555-559

38. Obadoni BO, Ochuko PO (2001) Phytochemical studies and comparative efficacy of the crude extract of some homeostatic plants in Edo and Delta states of Nigeria. Global J Pure Appl Sci 8:203-208

39. Van-Burden TP, Robinson T (1981) The biochemistry of alkaloids, 2nd edn. Springer. Heidelberg. New York

40. Blois MS (1958) Antioxidant determination by the use of a stable free radical. Nat 181:1199-1200

41. Saavedra MJ, Borges A, Dias C, Aires A, Bennett RN, Rosa ES, Simões M (2010) Antimicrobial activity of phenolics and glucosinolate hydrolysis products and their synergy with streptomycin against pathogenic bacteria. Med Chem 6:174-183

42. Ezeocha VC, Oti E (2013) Effects of waxing materials and storage periods on physico- chemical properties of trifoliate yam (Dioscorea dumetorum). Appl Sci Rep 4(2):219-224

43. Ezeocha VC, Ojimelukwe PC (2012) The impact of cooking on the proximate composition and antinutritional factors of water yam (Dioscorea alata). J Stor Prod Post-Harv Res 3(13):172-176

44. Tomas-Barberan FA, Espin JC (2001) Phenolic compounds and related enzymes as determinants of quality in fruits and vegetables. J Sci Food Agric 81:853-876

45. Barreira JCM, Ferreira ICFR, Oliveira MBPP, Pereira JA (2008) Antioxidant activity and bioactive compounds of ten Portuguese regional and commercial almond cultivars. Food Chem Toxicol 46:2230-2235

46. Akbari V, Jamei R, Heidari R, Jahanban Sfahlan A (2012) Antioxidant activity of different parts of Walnut (Juglans regia L.) fruit as a function of genotype. Food Chem 135:2404-2410

47. Hatamnia AA, Abbaspour N, Darvishzadeh R (2014) Antioxidant activity and phenolic profile of different parts of Bene (Pistacia atlantica subsp. kurdica) fruits. Food Chem 145:306-311

48. Cornago DF, Rumbaoa RGO, Geronimo IM (2011) Philippine Yam (Dioscorea spp.) tubers phenolic content and antioxidant capacity. Philippine J Sci 140(2):145-152

49. Sakthidevi G, Mohan VR (2013) Total phenolic, flavonoid contents and Invitro antioxidant activity of Dioscorea alata L. tuber. J Pharm Sci Res 5(5): $115-119$

50. Mittelstrass K, Ried JS, Yu Z, Krumsiek J, Gieger C et al (2011) Discovery of sexual dimorphisms in metabolic and genetic biomarkers. PLoS Genet 7: e1002215

51. Dormann CF, Skarpe C (2002) Flowering, growth and defense in the two sexes: consequences of herbivore exclusion for Salix polaris. Funct Ecol 16: 649-656

52. Boecklen WJ, Price PW, Mopper S (2004) Sex and drugs and herbivores: sexbiased herbivory in Arroyo Willow (Salix lasiolepis). Ecology 71:581-588

53. Cornelissen T, Stiling P (2005) Sex-biased herbivory: a meta analysis of the effects of gender on plant-herbivore interactions. Oikos 111:488-500 
54. Uribe-Mu CA, Quesada M (2006) Preferences, patterns and consequences of branch removal on the dioecious tropical tree Spondias purpurea (Anacardiaceae) by the insect borer Oncideres albomarginata chamela (Cerambycidae). Oikos 112:691-697

55. Orians CM, Roche BM, Fritz RS (1996) The genetic basis for variation in the concentration of phenolic glycosides in Salix sericea: an analysis of heritability. Biochem Syst Ecol 24:719-724

56. Palumbo MJ, Putz FE, Stephen TT (2007) Nitrogen fertilizer and gender effects on the secondary metabolism of yaupon, a caffeine-containing North American holly. Oecologia 151:1-9

57. Awah NS, Agu KC, Ilkedinma JC, Uzoechi AN, Eneite HC, Victor-Aduloju AT, Umeoduagu ND, Onwuatuegwu JTC, llikannu SO (2017) Antibacterial activities of the aqueous and ethanolic extracts of the male and female Carica papaya leaves on some pathogenic bacteria. Bioeng Biosci 5(2):25-29

58. Jigna P, Sumitra C (2006) In-vitro antimicrobial activities of extracts of Launaea procumbns Roxb. (Labiateae), Vitis vinifera (Vitaceae) and Cyperus rotundus L. (Cyperaceae). Afr J Biomed Res 9(2):89-93

59. Abd Razik BM, Hasan HA, Murtadha MK (2012) The study of antibacterial activity of Plantago major and Ceratonia siliqua. The Iraqi Postgraduate 11(1):130-135

60. Joshi B, Lekhak S, Shorma A (2009) Antibacterial property of different medicinal plants: Ocimum sanctum, Cinnamomum zeylanicum, Xanthoxylum armatum and Origanum majorana. Nepal J Online 5(1):143-150

\section{Publisher's Note}

Springer Nature remains neutral with regard to jurisdictional claims in published maps and institutional affiliations.

\section{Submit your manuscript to a SpringerOpen ${ }^{\circ}$ journal and benefit from:}

- Convenient online submission

- Rigorous peer review

- Open access: articles freely available online

High visibility within the field

- Retaining the copyright to your article

Submit your next manuscript at $\boldsymbol{\nabla}$ springeropen.com 